\title{
E-Waste: RENEW, RESUBJECT, REMASK AND RESALE
}

\author{
Ravi Raj \\ Department of Teacher Education \\ Central University of Himachal Pradesh \\ Dhauladhar, Himachal Pradesh, India
}

\author{
Kaushik Kumar \\ Department of Social Work \\ Central University of Himachal Pradesh \\ Dhauladhar Campus, Himachal Pradesh, India
}

\begin{abstract}
The earth is plundering with various types of wastes. Pollution is increasing on day by day with increase of technological drives and degrading our environment daily which has led to catastrophic changes in atmosphere across places in the globe. In ancient ages human being has regarded waste as useless subject .Ironically a Great Greek Philosopher LinardoVinci stated Waste is not a waste unless it becomes of use. Due to tremendous increase in technology there is lot of shift of waste from the western countries to the underdeveloped countries on the name of free trade. Due to lack of the awareness about electric and electronic products the people also are in enigma of the type of solid waste and ewaste in developed nations which worsen the condition more. Solid waste refers to that type of obsolete waste which is only composed of metal and supports no electric and electronic equipment while e-waste refers to those goods which were of electric and electronic equipment but became obsolete. The e- waste is also known as electronic waste. The $e-$ waste is the fastest known growing waste on this earth. There is need to reduce the mounting waste by some meaningful module
\end{abstract}

Key Words-e-Waste, Nature, Technology.

\section{INTRODUCTION}

Education has nurtured the human and will nurture in coming time. Human being came on this planet named earth where nature had life to reasons of sustainability. Globally today, after being technically advanced human is self-bounded by his created techno-hazards. Human being today is challenged by nature; Mother Nature in the womb of which life was gifted to him. Technology is unignorable aspect of life and it will only increase with growing time but technological awareness and proper up gradation of technology should be kept in mind as degraded electrical equipment leads to eWaste generation. Awareness about environment and proper safe guarding of its natural resources is necessary for creating a pollution free clean environmental arena. Society plays a pivotal role in shaping human behavior. It can be seen in the fact that the room shaped first successfully operative digital device E-waste is the fastest growing type of waste. This is hazardous and non-biodegradable also. According to Step (2012), today human is standing on the heaping waste of million tones which is produced by both the developed and developing countries. Mankind is linked with natural developments and also has to keep balance with technological developments as in previous years the planet has been equipped to many natural hazard and disasters taking many lives. Harmonious growth of human life or sustainable development is necessary for the proper channelization for our next coming generations to fruit in on in this planet. It is necessary to understand with the peaceful mind the context of the developments of earlier. The developments during the last decade assumed role of providing forceful leverage to the socioeconomic and technological growth of developing society. Digitization caused arousal of many new brands in industry and market. This was a reason of technological unbalance around the globe because of being digitally divided. The lack of Human Environmental Awareness and digital literacy became a major barrier in path of increasing informal waste in market. As time is changing rapidly, people have to become aware and curious towards the techno-revolution. The mankind is today largely dependent on technology. The story doesn't stop here but problem begins when these appliances get induced with software problems and causing sow internet speed and software problem. Secondly the lifetime of these products is getting reduced due to which e-waste is increasing. Today, technology is characterized with speed and consistent improvement concepts. Awareness and in-depth understanding of the products being used is necessary to know pros and cons of it. Every company demarcates the symbols behind its product which consumer must see and notice. The unawareness or ignorance of it by human being leads to increase in waste hazardous waste products. There is lack of curriculum of Environment Education and Disaster Management worldwide at the primary stage in majority of nations due to which psychologically there keeps question to mind of unawareness of some growing presently aspects of environmental pollution. Value Aided Technological Environmental Education courses to 
all peoples with help of international organizations in each part of globe around the society can put a hangover to the amounting volumes of e-waste in the society and increase awareness among the people. Psychological education content development seems to be remedial boon of the ewaste problem. Only psychological e-technical lessons can increase awareness among the people and redirect then to recycle reuse and hazardous content of e-waste more effectively

E-Waste is nowadays considered as the fastest growing hazardous types of waste .People are mostly confused between two types of waste i.e. solid waste and e-waste. Solid waste on one hand deals only with metallic obsolete waste while eWaste deals with electric and electronic waste particle which become obleselete and are of no more of usage. Electronic waste which has surprisingly recently plundered its growth in the waste market is not dubious in nature but is because of the fact that technology aided people are not using the technological devices as per the notified

\begin{tabular}{|c|c|c|c|}
\hline & Item1 & Himachal & Punjab \\
\hline \multirow{5}{*}{$\begin{array}{l}\text { Which is } \\
\text { the } \\
\text { fastest } \\
\text { growing } \\
\text { waste in } \\
\text { India? }\end{array}$} & $\begin{array}{l}\text { Biomedical } \\
\text { waste }\end{array}$ & $21.0 \%$ & $22.0 \%$ \\
\hline & $\begin{array}{l}\text { Municipal } \\
\text { waste }\end{array}$ & $46.0 \%$ & $52.0 \%$ \\
\hline & e-Waste & $32.0 \%$ & $20 \%$ \\
\hline & $\begin{array}{l}\text { None of } \\
\text { Above }\end{array}$ & $1.0 \%$ & $6.0 \%$ \\
\hline & Total & \multicolumn{2}{|l|}{$100 \%$} \\
\hline
\end{tabular}

guidelines

\section{REVIEW}

Poornalakshmi, et.al (2015) did a quantitative study using test \& post-test design on sample of 1500 graduate students of different streams in a Technical College, Chennai, Tamil Nadu with the objective to study the effectiveness of E-waste and correlate the knowledge and attitude of college students. The researcher found that there was significant difference in level of knowledge and attitude score regarding E-waste among college students

Sakshi and Sushma Gupta (2014) did a quantitative study on the sample of 200 students on perspectives of e-waste awareness among college students $\mathrm{w} \mathrm{rt}$ gender, stream and socioeconomic status. The study focused on awareness of e- waste. The researcher concluded that the male college students are more aware about electronic waste.

Suzuki, S et.al (2001) conducted a study A Survey of Perception, Knowledge, Awareness, and attitude in Regard to Environmental Problems in a Sample of two Different Social Groups in Jakarta, Indonesia

\section{SAMPLE AND SAMPLING TECHNIQUE}

The research study was carried on two districts of Himachal Pradesh on basis of simple random sampling technique. The study was carried on the sample of 400respondents from district Hamirpur and district Ludhiana on basis of literacy level. The 50 respondents were taken from each of 4 college selected from the district. The main purpose of the present study is to judge e-Waste Awareness among Higher Educational Institutes of Himachal Pradesh and Punjab. The researcher was unable to find suitable research tools to meet the requirement of the study. Thus, the researcher decided to construct following own research tools under the supervision and guidance of his research supervisor.

\section{Main Findings}

TABLE-4.1 shows awareness percentage about "which is the fastest growing waste in India" among higher educational institutes of Himachal and Punjab

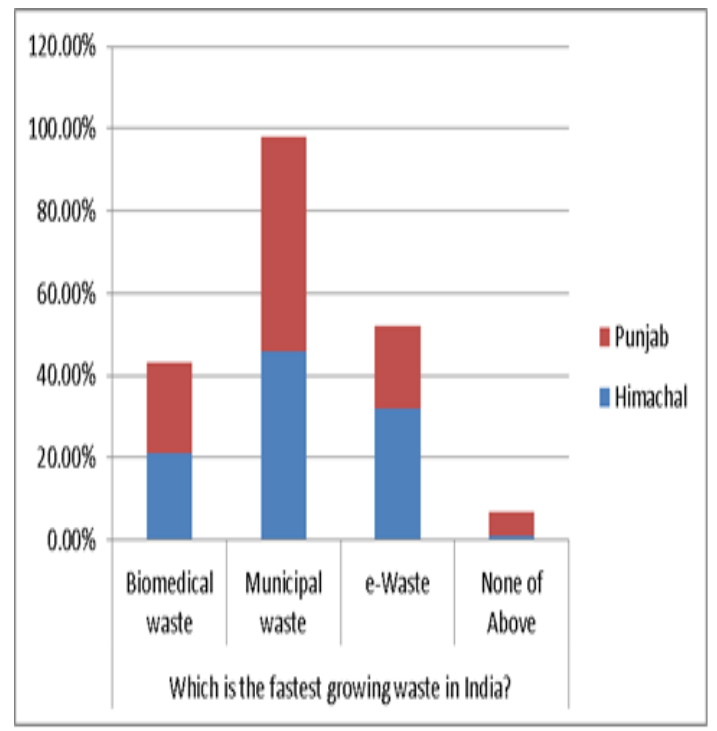

Table -4.2 Shows the percentage awareness in respect of "Tick on the electronic gadgets that has shortest discard rate" among Higher Educational Institutes of Himachal and Punjab.

\begin{tabular}{|c|c|c|c|}
\hline \multirow{2}{*}{\multicolumn{2}{|c|}{ ITEM-2 }} & \multirow{2}{*}{\multicolumn{2}{|c|}{ State }} \\
\hline & & & \\
\hline Tick on & Mobiles & $\begin{array}{l}\text { Himacha } \\
\text { l } \\
27.0 \%\end{array}$ & $\begin{array}{l}\begin{array}{l}\text { Punja } \\
\text { b }\end{array} \\
28.0 \%\end{array}$ \\
\hline & Televisions & $21.0 \%$ & $21.0 \%$ \\
\hline electroni & Computer & $38.0 . \%$ & $32.0 \%$ \\
\hline $\begin{array}{l}\text { c gadget } \\
\text { that } \\
\text { has } \\
\text { shortest } \\
\text { discard } \\
\text { rate }\end{array}$ & $\begin{array}{l}\text { Refrigerato } \\
\mathrm{r}\end{array}$ & $14.0 \%$ & $19.0 \%$ \\
\hline
\end{tabular}


The table 4.2 above shows the percentage awareness in respect of "Tick on the electronic gadgets that has shortest discard rate" The correct response to this is "Mobiles" responded to by $27 \%$ of respondents of Himachal and $28 \%$ respondents of Punjab. "Television" on the other hand was responded to by $21 \%$ of Himachal respondents and $21 \%$ of Punjab respondents. "Computer" was responded to by $38 \%$ of respondents of Himachal Pradesh and $32 \%$ of Punjab respondents, while "Refrigerator" was the choice of $19 \%$ of Punjab respondents and $14 \%$ of Himachal respondents

Fig 4.2 percentage awareness in respect of "tick on electronic gadget that has shortest discard rate" among Higher Educational Institutes of Himachal and Punjab

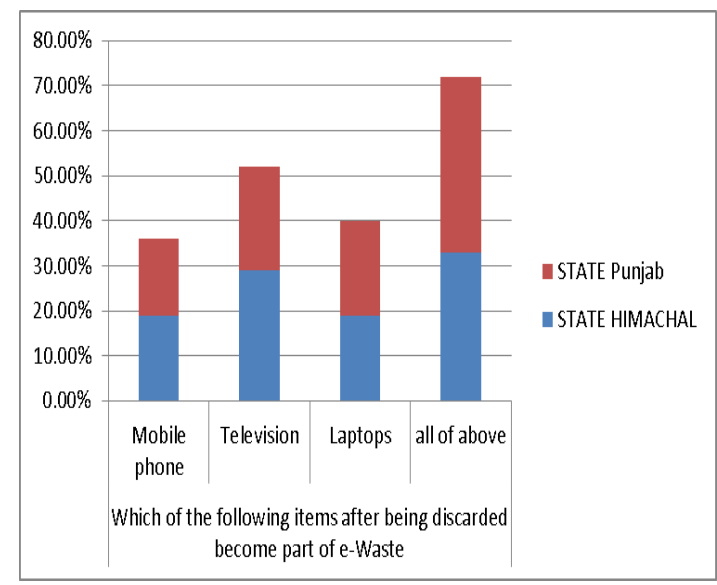

Table 4.3Shows the percentage awareness in respect of "E-Waste Terminology Refers To" among Higher Educational Institutes Of Himachal / Punjab

\begin{tabular}{|c|c|c|c|}
\hline \multirow{2}{*}{\multicolumn{2}{|c|}{ ITEM-2 }} & \multicolumn{2}{|l|}{ STATE } \\
\hline & & Himachal & TPunjab \\
\hline \multirow{4}{*}{$\begin{array}{l}\text { e-Waste } \\
\text { terminology } \\
\text { refers to }\end{array}$} & \begin{tabular}{|l} 
Electronic \\
Waste
\end{tabular} & $40.0 \%$ & $46.0 \%$ \\
\hline & $\begin{array}{l}\text { Electric } \\
\text { Waste }\end{array}$ & $48.0 \%$ & $44.0 \%$ \\
\hline & \begin{tabular}{|l} 
E- \\
Technology \\
Waste
\end{tabular} & $7.0 \%$ & $8.0 \%$ \\
\hline & $\begin{array}{l}\text { None of } \\
\text { these }\end{array}$ & $5.0 \%$ & $2.0 \%$ \\
\hline
\end{tabular}

e-waste Terminology Refers To" The correct response to the item of the given scale is "electronic Waste" a response that was given by only $40 . \%$ of Himachal respondents and $60 \%$ of respondents of Punjab. The next option "electric waste" was the response given by $48 \%$ respondents in Himachal and $44 \%$ of respondents of Punjab. Response to the next and the last item in the list "E-technology" was responded to by $7 \%$ in Himachal and $8 \%$ in Punjab. Similarly "none of the above" was responded to by only 5\% in Himachal and 2\% in Punjab.

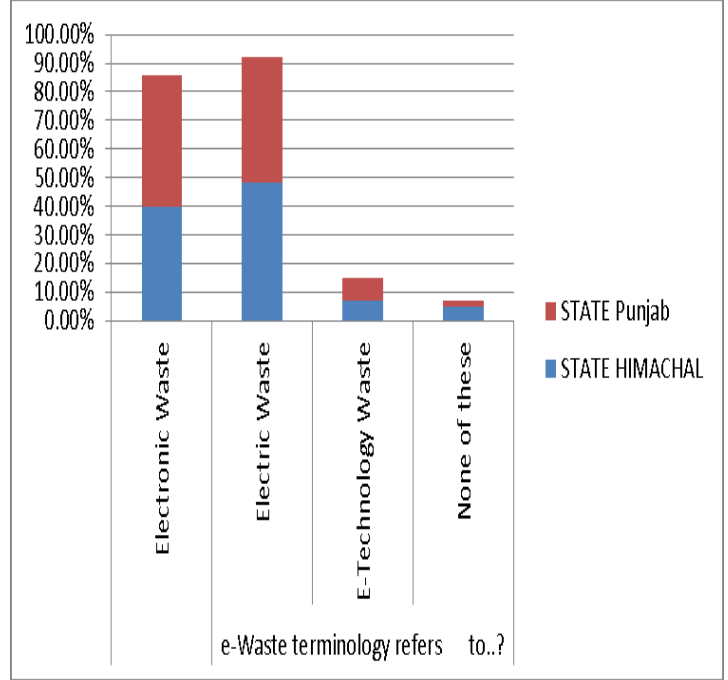

HYPOTHESIS-1: There will be no significant difference between e-Waste awareness in the total sample higher educational institutes of Himachal Pradesh and Punjab

The data obtained on basis of above hypothesis are listed below in table 4.41

Table 4.4 Mean, SD \& ' $t$ ' value of e-Waste awareness among the total sample of Higher Educational Institutes of Himachal and Punjab

\begin{tabular}{|l|l|l|l|l|l|}
\hline $\begin{array}{l}\text { Catego } \\
\text { ry }\end{array}$ & Sate & N & $\begin{array}{l}\text { Mea } \\
\text { n }\end{array}$ & SD & $\begin{array}{l}\text { 't' } \\
\text { value }\end{array}$ \\
\hline $\begin{array}{l}\text { Total } \\
\text { sample }\end{array}$ & Himachal & 400 & $\begin{array}{l}44.8 \\
2\end{array}$ & 5.88 & $\mathbf{2 . 3 4}$ \\
\cline { 2 - 5 } & Punjab & 400 & $\begin{array}{l}41.7 \\
8\end{array}$ & 7.07 & \\
& & & 8 & \\
\hline
\end{tabular}

Analysis of data based on the table 4.4 shows eWaste awareness of higher educational institutes in the total sample, the mean values obtained are 44.84 for Himachal and 41.78 for Punjab respectively. The ' $t$ ' value obtained was 2.34 which is significant at .01 level of significance. This shows that there is significant difference in the value eWaste awareness of Higher Educational institutes of Himachal and Punjab. Hence hypothesis is rejected.

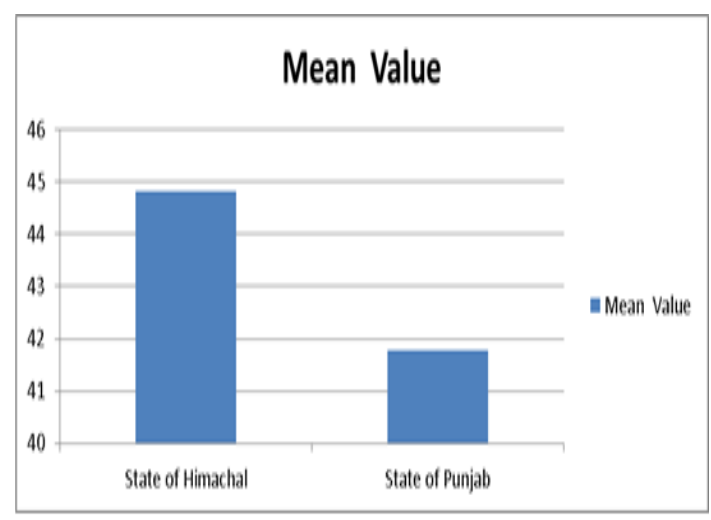




\section{International Journal of Engineering Applied Sciences and Technology, 2019 \\ Vol. 4, Issue 4, ISSN No. 2455-2143, Pages 123-127 \\ Published Online August 2019 in IJEAST (http://www.ijeast.com)}

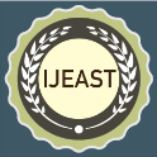

\section{CORE STRATEGY FRAMEWORK}

From the above studies and findings the researcher derived 4R e-Waste strategy. According to this strategy there is main customer is directly linked with product and manufacturer. The manufacturer is bounded to retailer for future benefits. E- Waste which is growing needs to be piled up but it a concrete and natural substance which is to be understood that technology will grow and e-waste will tend to increase at door steps. Though it can't be completely uprooted and elemental but some steps can be taken to decrease the increasing amount of e-waste generation. Firstly society will have to move toward Enron mental education curriculum from the basic standard classes so that person should clearly come to know about type of waste. Still there is lot of dilemma about e-waste and solid waste.

1. Renew: In this the collection centers should be setup near the e-waste places. The old laptop, mobile, and other e-waste material will be replaced with working parks of other devices available in same place. The device will be sold to the customer at a cheaper rate.

2. Re-subject. The e-waste products are totally designed in different way. Now in case of resubject the particle of electronic waste are reformed into different kinds of toys. These may be built up in a garden for increasing awareness of people and hence money can be surcharged at each visit

3. Remask; in this case different things are made from e-waste, for example laptop scrap can be to designs on walls

4. Resale. A product if keeps on working for a durable time and shows sustainability then it should be updated and given for resale after a specific time.

\section{CONCLUSION}

Lack of human awareness to advancing technology or precautious usage of software and hardware process has resulted to pythons increase in amount of e-waste. Technology will keep on advancing and come with new innovations. Only man has to take a step to change himself by increasing awareness and utility of products. All know waste will increase but it is better if we do something it that tendency of increase slows down.

\section{REFFERENCES}

1. Kumar, etal (2013). E-Waste Management in India: Issues and Options,International Journal of Languages, Education and Social Sciences, Vol. 02, Issue 01, Sept 2012 retrieved from http://www.ijless.com/journal\%20data/STATU S\%200F\%20E-WASTE.pdf on 22 March 2014

2. Kumar, U., Ramesh Kumar, P., Sharma, S., \& Singh, D. N. (2014). Electronic Waste Study \& Facts in Bihar. International Journal Of Engineering And Computer Science, 3(11). Retrieved from: www.ijecs.in

3. Rakib, M. A., and Ali, M. (2014). Electronic waste generation: observational status and local concept along with environmental impact. International Journal of Scientific Research in Knowledge, 2(10), 470. Available online at http://www.ijsrpub.com/ijsrk

4. Ritu, S., and Shalini, A. (2013). Knowledge of E-waste among young adults. International Journal of Engineering Science Invention, 2, 39-41. Retrieved from: www.ijesi.org

5. Poornalakshmi, Manonmani, Kanchana, S. and Celina, D. (2015).Effectiveness of E-Waste Management Educational Package on Knowledge Attitude Regarding E-Waste among College Students. International Journal of Comprehensive Nursing, 2(7). Retrieved from: http://www.ijcn.mainspringer.com/Vol2/2_7/cn 20603.pdf

6. Peralta, G. L., and Fontanos, P. M. (2006). Ewaste issues and measures in the Philippines. Journal of material cycles and waste management, 8(1), 34-39. Retrieved from: https://link.springer.com/article/10.1007/s10163 -005-0142-5

7. Jain A. and Sareen R.(2006) conducted a study E-waste assessment methodology and validation in India, which aimed at establishing an approach and a methodology for quantify the total electronic waste in India.

8. Bains, N.,et al. (2007). An integrated approach to electronic waste (WEEE) recycling, Circuit World, 33(2), 52-5. Retrieved from http://www.emeraldinsight.com/search.htm?st1 $=$ electronic + waste $\& \mathrm{ct}=\mathrm{all} \& \mathrm{ec}=1 \& \mathrm{bf}=1 \& \mathrm{~g}_{0}=\mathrm{Go} \quad$ on September30, 2013.

9. Basel Convention (2010), Ministerio de Ambiente, Vivienda y Desarrollo Territorial, BICENANTRIO:Project Summary (2010), República de Colombia. Retrieved from 
International Journal of Engineering Applied Sciences and Technology, 2019

Vol. 4, Issue 4, ISSN No. 2455-2143, Pages 123-127

Published Online August 2019 in IJEAST (http://www.ijeast.com)

http://www.basel.int/Portals/4/Basel\%20Conve ntion/docs/convention/XX\%20Anniversary/Pre ss\%20kit/Colombia\%20Project\%20leaflet.pdf on Oct 29, 2013.

10. Chan, A., et al (2010). Developmental Neurotoxicants in A-Waste: An Emerging Health Concern, Environ Health Perspect, 1(4), pp 431-438. Retrieved from http://www.jstor.org/stable/pdf retrieved on October 2, 2013.

11. Ching, R., and Gohan, R. (1992). Campus recycling: everyone plays a part. New Dir Higher Educ.1992; 77: 113-125

12. Fien, S. (2010).Frontiers in Ecology and the Environment, Ecological Society of America, 8(3), 117.Retrieved from http://www.jstor.org/stable/pdf on August21, 2013.

13. Grant, R. and Oteng-Ababio, M. (2012). Mapping the invisible and real "African" economy: Urban e-Waste circuitry: Urban Geography, pp.33, pp. 1-2. 